\title{
Gastric Mucosa-Associated Lymphoid Tissue Lymphoma
}

National Cancer Institute

\section{Source}

National Cancer Institute. Gastric Mucosa-Associated Lymphoid Tissue Lymphoma. NCI

Thesaurus. Code C5266.

A low grade, indolent B-cell lymphoma, usually associated with Helicobacter pylori infection. Morphologically it is characterized by a dense mucosal atypical lymphocytic (centrocyte-like cell) infiltrate with often prominent lymphoepithelial lesions and plasmacytic differentiation. Approximately $40 \%$ of gastric MALT lymphomas carry the $\mathrm{t}(11 ; 18)(\mathrm{q} 21 ; \mathrm{q} 21)$. Such cases are resistant to Helicobacter pylori therapy. 